\title{
Glycoconjugate composition of ovine parotid glands elucidated by lectins
}

\author{
ÇINAR, K. ${ }^{1}$, ÖZTOP, $M .^{2 *}$ and ÖZKARASU, B. ${ }^{1}$ \\ ${ }^{1}$ Department of Biology, Faculty of Sciences and Art, Süleyman Demirel University, \\ Isparta-Afyon Karayolu 8. Km, Çünür Doğu Yerleşkesi, 32260, Isparta, Turkey \\ ${ }^{2}$ Department of Biology, Faculty of Sciences and Art, Mehmet Akif Ersoy University, \\ Antalya-Burdur Karayolu 8. Km, İstiklal Yerleşkesi, 15100, Burdur, Turkey \\ *E-mail: mustafa_oztop@yahoo.com
}

\begin{abstract}
Introduction: This study aimed to determine the distribution of glycoconjugates found in sheep (Ovis aries) parotid glands by lectin histochemistry. Methods: Following routine histological tissue processing, tissue sections

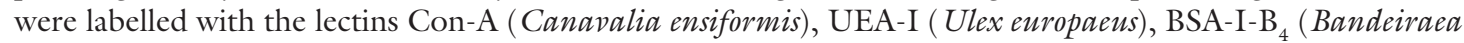
simplicifolia), PNA (Arachis hypogaea), WGA (Triticum vulgaris) and SBA (Glycine max). Results: The results of lectin staining indicated that fucose sugar was the most abundant sugar on the surface of serous cells, although absence of $\mathrm{N}$-acetylgalactosamine on the serous cells surface. Fucose, $\mathrm{N}$-acetylglucosamine, mannose, galactose, and $\mathrm{N}$-acetylgalactosamine were present on the surface of duct cells. All lectins stained with duct epithelial cells in a similar manner - from weak to moderate. Serous cells were labelled with all the lectins, except for PNA, in various degrees. Conclusion: The data obtained from this study can provide new insight into characterizing the glycoconjugate profiles in different species in an effort to be capable of understanding detailed structure and function of parotid gland in both normal- and abnormal states.
\end{abstract}

Keywords: Ovis aries, parotid gland, lectin histochemistry, glycoconjugate, sheep.

\section{Introduction}

Terrestrial animals possess salivary glands, which are exocrine glands that are scattered throughout the oral cavity and also located outside of oral cavity (MILETICH and TUCKER, 2010; MESCHER, 2013). Salivary glands are classically divided into major and minor salivary glands. Major salivary glands are large glands located at a distance from the oral mucosa, which empty their secretions in the oral cavity through long extra-glandular ducts. Major salivary glands comprise three pairs of glands, namely the parotid, submandibular and sublingual glands, which secrete $90 \%$ of the total saliva (MILETICH and TUCKER, 2010). Parotid glands, which are the largest ones, are located at a retromandibular position and have a branched acinar structure produce about $25-35 \%$ of the total saliva. The serous cell predominates in the parotid, making the gland secrete a mainly serous secretory product (BATH-BALOGH and FEHRENBACH, 2011; HAND and FRANK, 2015).

Saliva performs a wide array of physiologic and protective functions, some of which are related to its fluid properties and others to its specific content of a variety of molecules (PEDERSEN, BARDOW, JENSEN et al., 2002). Being a saliva liquid in nature primarily lubricates the oral mucosa lining the inside of the mouth and moistens food bites. As such, it cleans the oral cavity by flushing away food debris and bacteria, helps with mastication and swallowing of the food bolus, facilitates speech, and, last but not least, allows taste perception by solubilizing food chemicals, an essential step for the stimulation of receptor cells of the taste buds (ZELLES, PURUSHOTHAM, MACAULEY et al., 1995; REECE, 2005; GRÖSCHL, 2009). Although mostly composed of water, saliva also contains electrolytes and an incredible variety of proteins and peptides that fulfil numerous functions.
Specific components actively secreted in the saliva are key to maintaining the good health of the oral cavity. Saliva protects the teeth through the presence of negatively charged proteins that bind to hydroxyapatite minerals on the enamel surface of tooth crowns. Through its high bicarbonate concentration, it buffers acids produced by the dental plaque bacteria when carbohydrates are fermented, thereby preventing tooth decay (ZELLES, PURUSHOTHAM, MACAULEY et al., 1995; KOEPPEN and STANTON, 2008; GRÖSCHL, 2009; GUYTON and HALL, 2010). Saliva also provides protection to the oral mucosa lining the inside of the mouth, via an array of antimicrobial agents including secretory immunoglobulin A, lysozyme and lactoperoxidase (ZELLES, PURUSHOTHAM, MACAULEY et al., 1995; SCANLON and SANDERS, 2007; GRÖSCHL, 2009; TORTORA and DERRICKSON, 2012). In addition to its defensive role, saliva also initiates the digestion of starches and a small fraction of triglyceride lipids through $\alpha$-amylase and lipase enzymes, respectively (KOEPPEN and STANTON, 2008; GUYTON and HALL, 2010; MESCHER, 2013). However, these two enzymes are considered to be of minor significance in healthy individuals since they are rapidly inactivated by gastric acidity. Apart from components having an obvious function, saliva also exhibits a tremendous variety of biologically active proteins in the form of growth factors and other small peptides (ZELLES, PURUSHOTHAM, MACAULEY et al., 1995; GRÖSCHL, 2009).

In addition to those mentioned above, the saliva comprises a considerable amount of mucus. Glycoproteins present in the mucus participate in many cellular processes and play an active role in recognizing the cell surface by viruses and other substances (ÜNÜBOL and UYSAL, 2010). Mucin glycoproteins 
have all characteristics of a protein, and of sugars under certain conditions. Enzymes, radioactive labelling, antibodies and lectins are used to identify the sugar residues in the cells. In this respect, use of the lectins has become even more important in recent years (KARAÇALI, 2003).

Lectins are proteins or glycoproteins, which are of non-immune origin and are derived from plants, animals, or microorganisms that have specificity for terminal or subterminal carbohydrate residues. Lectin histochemistry can provide an extremely sensitive detection system for changes in glycosylation and carbohydrate expression that may occur during embryogenesis, growth, and disease. Lectin histochemistry can also reveal subtle alterations in glycosylation between otherwise indistinguishable cells (RHODES and MILTON, 1998; ROTH, 2011). Some studies have been carried out to determine the glycoconjugates found in parotid glands of some species by lectin histochemistry (SCHULTE and SPICER, 1983, 1984; LADEN; SCHULTE and SPICER, 1984; TOLSON, DALEY and WYSOCKI, 1985; JEZERNIK and PIPAN, 1986; VIGNESWARAN, HANEKE and HORNSTEIN, 1989; ACCILI, MENGHI, BONDI et al., 1992; GARGIULO, PEDINI and CECCARELLI, 1993; PEDINI, CECCARELLI and GARGIULO, 1994, 1995; PEDINI, CECCARELLI, GARGIULO et al., 1997; KIMURA, HABATA, ENDO et al., 1998; SÖZMEN, BROWN and EVESON, 1999; ADNYANE, WRESDIYATI, WIBAWAN et al., 2006; MUNYALA, LIUMSIRICHAROEN, PONGKET et al., 2009; SOBRAL, REGO, CAVALACANTI et al., 2010). To the best of our knowledge, there is no study that determines the distribution of glycoconjugates in sheep (Ovis aries) parotid glands by use of lectins. This study aims to determine the glycoconjugates in sheep parotid glands using six lectins

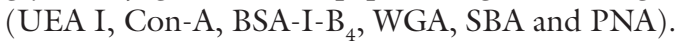

\section{Materials and Methods}

\subsection{Tissue processing}

Samples of parotid glands of 10 adult sheep (Ovis aries) supplied from Isparta Slaughter House and Gülköy Meat Integrated Plant (Isparta, Turkey) were immediately immersed in Bouin's fixative and fixed for 16 to 18 hours at room temperature. After fixation and washing three times in $50 \%$ of alcohol, the tissues were dehydrated in series of ascending ethanol, cleared in xylene and embedded in paraffin. Serial 5-7 $\mu \mathrm{m}$-thick sections were cut and collected on albumin-coated slides.

\subsection{Lectin bistochemistry}

Lectin histochemistry was employed to determine the distribution and characters of glycoconjugates in parotid glands of sheep. According to this procedure, after dewaxing in xylene and rehydrating in descending grades of ethanol, the sections were washed in distilled water. The sections were incubated with $0.3 \% \mathrm{H}_{2} \mathrm{O}_{2}(\mathrm{v} / \mathrm{v})$ in absolute methanol for 10 minutes at room temperature in order to block endogenous peroxidase activities. After rinsing in distilled water and washed in $0.01 \mathrm{M}$ PBS (Phosphate Buffered Saline) ( $\mathrm{pH} 7.2$ ) containing 1\% BSA (Bovine Serum Albumin), the sections were then incubated with a panel of Horseradish Peroxidase (HRP)-conjugated lectins for 30 minutes at room temperature and washed in PBS. The HRP-conjugated lectins, their binding specificities and optimal concentrations used in this study are listed at Table 1 . The lectin binding sites were then visualized by DAB (3,3-diaminobenzidine tetrahydrochloride) for 10 minutes at room temperature and appeared as brown or dark-brown colors. Slides developed with DAB were washed in distilled water, dehydrated in ascending grades of alcohol, cleared in xylene, permanently mounted with Entellan and examined under light microscope (Olympus, CX 41) and photographed using a digital camera mounted on the microscope.

\subsection{Negative control}

The sections were incubated with free-lectin PBS for $30 \mathrm{~min}$ at room temperature and the same procedure was followed.

\section{Results}

The lectin histochemical staining demonstrated positive reactions of various intensities for different glycoconjugates in the secretory endpieces of the parotid salivary gland of sheep (Ovis aries). The main findings are summarized in Table 2. A very strong reaction to the lectin UEA-I was disclosed on the surfaces of glandular epithelial cells in serous corpus glandula, whereas a moderate reaction against this lectin was detected in the cytoplasm of the glandular epithelial cells. The lectin UEA-I stained weakly to moderately epithelial cells of the duct although a stronger to strong reaction to UEA-I showed on the luminal surfaces of duct (Figure 1). A moderate reaction to the lectin Con-A was detected on the apical surfaces of glandular epithelial cells in serous corpus glandula, as a weak reaction against this lectin was noticed in the cytoplasm of the glandular epithelial cells. The lectin Con-A stained weakly to moderately epithelial cells of the duct although a moderate to strong reaction to Con-A showed on the luminal surfaces of duct (Figure 2). A moderate reaction to the lectin BSA- $\mathrm{IB}_{4}$ was detected on the apical surfaces of glandular epithelial cells in serous corpus glandula, while a weak reaction against this lectin was observed in the basal parts of the serous glandular epithelial cells. Even though a strong to stronger reaction with $\mathrm{BSA}-\mathrm{IB}_{4}$ was observed in the ducts and on the apical surface of epithelial cells in the duct, this reaction was weak

Table 1. Lectins used in histochemical studies on the sheep parotid gland.

\begin{tabular}{|c|c|c|}
\hline Lectin (Acronym) & Carbohydrate binding specificity ${ }^{\mathrm{a}, \mathrm{b}}$ & Concentration $(\mu \mathrm{g} / \mathrm{mL})$ \\
\hline Canavalia ensiformis (Con-A) & $\alpha \operatorname{Man}>\alpha \mathrm{Glc}>\alpha \mathrm{GlcNAc}$ & $50 \mu \mathrm{g} / \mathrm{mL}$ \\
\hline Ulex europaeus (UEA-I) & $\alpha \mathrm{L}-\mathrm{Fuc}$ & $25 \mu \mathrm{g} / \mathrm{mL}$ \\
\hline Bandeiraea simplicifolia (BSA I- $\mathrm{B}_{4}$ ) & $\alpha$ Gal $>\alpha$ GalNAc & $25 \mu \mathrm{g} / \mathrm{mL}$ \\
\hline Arachis hypogaea (PNA) & Galß1,3GalNAc $>\alpha$ and $\beta$ Gal & $25 \mu \mathrm{g} / \mathrm{mL}$ \\
\hline Triticum vulgaris (WGA) & $\operatorname{GlcNAc}(\beta 1,4 \mathrm{GlcNAc})_{1-2}>\beta \mathrm{GlcNAc}>\mathrm{Neu} 5 \mathrm{Ac}$ & $25 \mu \mathrm{g} / \mathrm{mL}$ \\
\hline Glycine max SBA & $\alpha-$ GalNAc $=\beta-$ GalNAc $>\alpha-$ Gal & $25 \mu \mathrm{g} / \mathrm{mL}$ \\
\hline
\end{tabular}

${ }^{\mathrm{a} C a r b o h y d r a t e ~ s p e c i f i c i t i e s ~ o f ~ l e c t i n s ~ a r e ~ a c c o r d i n g ~ t o ~ L i e n e r, ~ S h a r o n ~ a n d ~ G o l d s t e i n ~(1986) ; ~}{ }^{\mathrm{b}}$ Abbreviation: Man, mannose; Glc, glucose; GlcNAc, N-acetylglucosamine; Gal, galactose; Neu5Ac, 5-acetylneuraminic acid; GalNAc, N-acetylgalactosamine; Fuc, fucose; Neu5Gc, 5-glycolylneuraminicacid; NeuNAc, N-acetylneuraminic acid. 
in the nucleus (Figure 3). Some glandular epithelial cells in the serous corpus glandula and ductal epithelial cells showed a weak reaction with SBA. This reaction with SBA was strong to stronger on the surfaces of the ductal epithelial cells (Figure 4). Any glandular epithelial cell of serous corpus glandula showed no reaction with PNA. Conversely, a strong to stronger reaction against PNA observed on the surfaces of ductal epithelial cells, with a moderate reaction to PNA in the ductal epithelial cells (Figure 5). Glandular epithelial cell of serous corpus glandula showed a reaction with WGA from weak to strong. A strong to stronger reaction against WGA observed on the surfaces of ductal epithelial cells, while it was a weak reaction to WGA in the ductal epithelial cells (Figure 6).

\section{Discussion}

Glycoconjugates play important roles in tissue formation and undergo changes in their characteristics and distribution as the cells differentiate and age (OMELYANENKO, SLUTSKY and MIRONOV, 2013). Lectin staining makes it possible to

Table 2. General pattern of lectin staining in the ovine parotid gland.

\begin{tabular}{llcccccc}
\hline \multicolumn{1}{c}{ Cell Type } & UEA-I & Con-A & BSA-IB $_{4}$ & PNA & SBA & WGA \\
\hline Serous corpus & Cell surface & 4 & 2 & 1 & 0 & $0 / 1$ & $1 / 2$ \\
glandula & Epithelial cells & 2 & 1 & 2 & 0 & 1 & $1 / 3$ \\
Excretory ducts & Cell surface & $3 / 4$ & $3 / 4$ & $3 / 4$ & $3 / 4$ & $3 / 4$ & $3 / 4$ \\
& Epithelial cells & $1 / 2$ & $1 / 2$ & 1 & 2 & 1 & 1 \\
\hline
\end{tabular}

Reaction intensity: $0=$ no reaction visible; $1=$ weak; $2=$ moderate; $3=$ strong; $4=$ very strong.

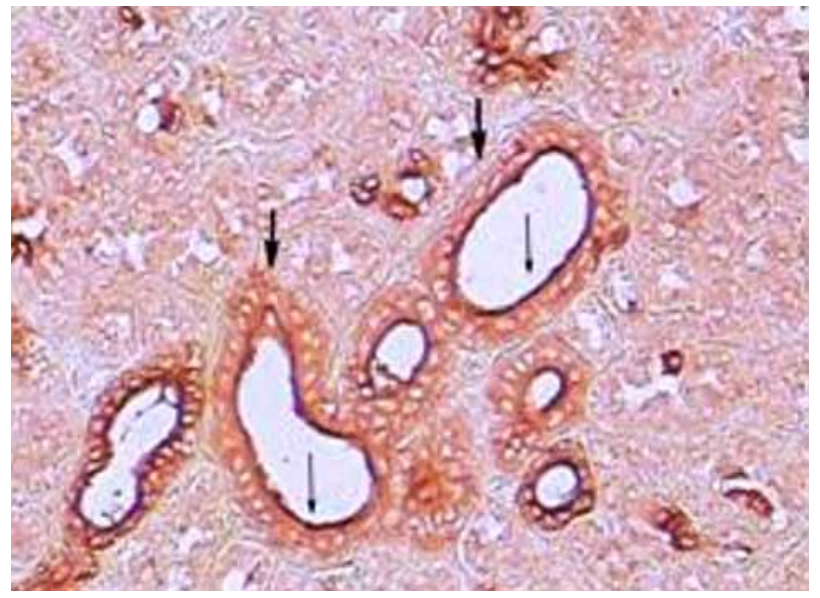

Figure 1. Strong to very strong UEA-I staining on the luminal surface (thin arrows); weak to moderate UEA-I staining at ductal epithelial cells (Thick arrows). x200.

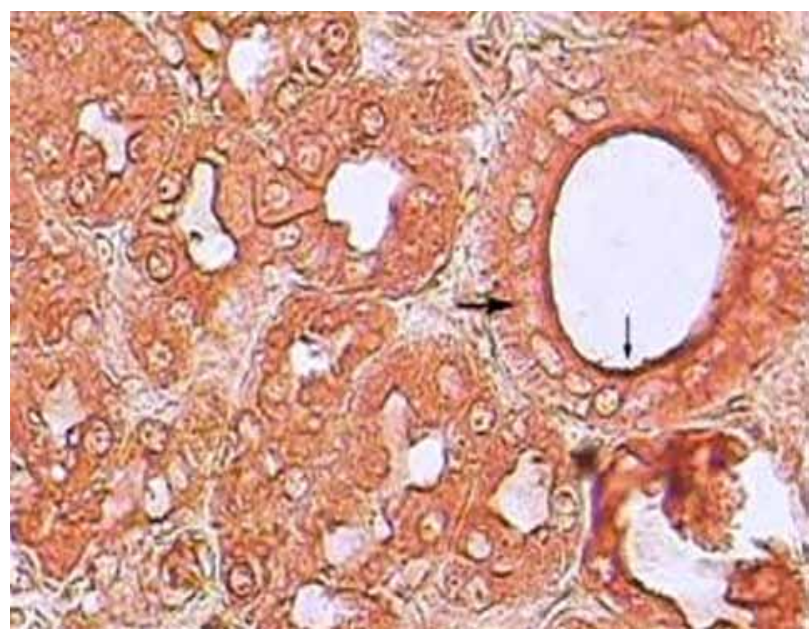

Figure 2. Moderate to strong Con-A staining on the luminal surface (thin arrows); weak to moderate Con-A staining at ductal epithelial cells (Thick arrows). x200.

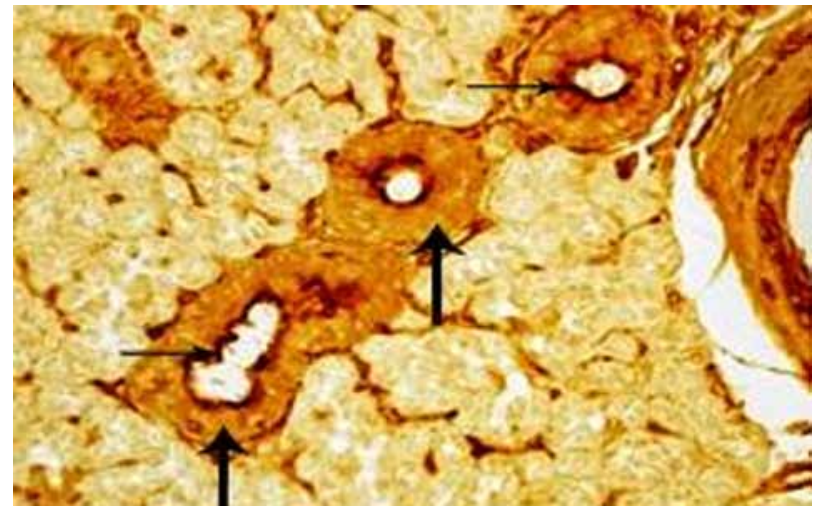

Figure 3. Strong to very strong BSA-I- $\mathrm{B}_{4}$ staining on the luminal surface (thin arrows); weak BSA-I-B 4 staining at ductal epithelial cells (Thick arrows). x200.

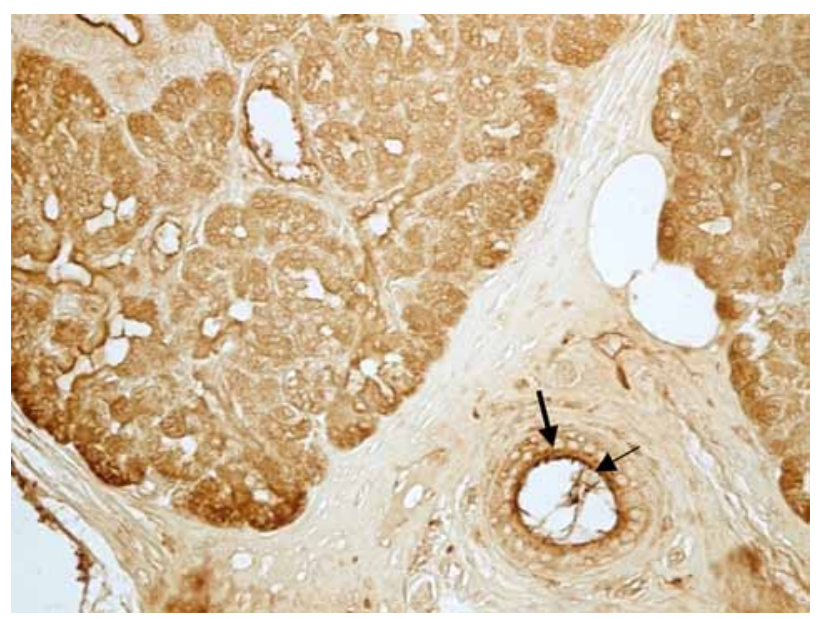

Figure 4. Strong SBA staining on the luminal surface (thin arrows); weak SBA staining at ductal epithelial cells (Thick arrows). Scale: $\mathrm{x} 200$. 


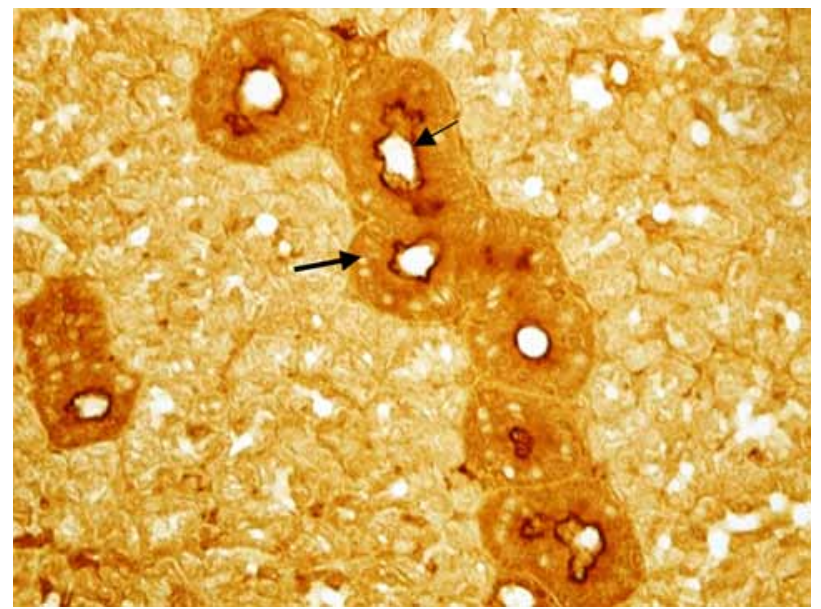

Figure 5. Strong PNA staining on the luminal surface (thin arrows); moderate PNA staining at ductal epithelial cells (Thick arrows). Scale: $x 200$.

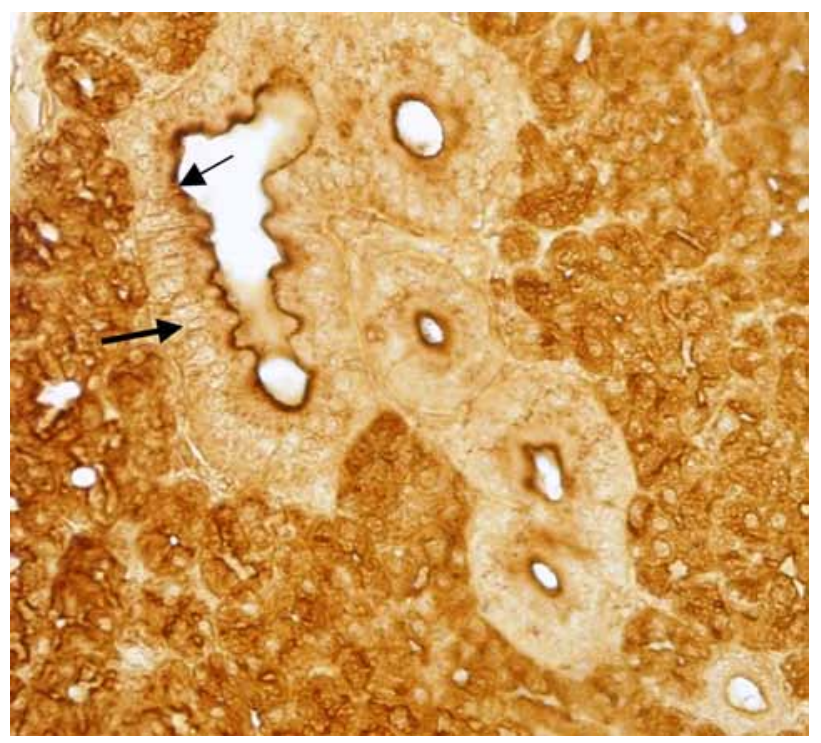

Figure 6. From weak, moderate to strong WGA staining on the luminal surface (thin arrows); weak WGA staining at ductal epithelial cells (Thick arrows). Scale: $x 200$.

identify various types of glycoconjugates. Ikeda and Aiyama $(1997,1999)$ showed that the secretory granules of the early postnatal rat parotid gland mucous cells react with SBA, PNA and WGA lectins. This finding confirmed that the mucous cells on the onset of gland development contained $\beta$-D-galactose $(\beta$-D-Gal), $\alpha$-D-Nacetylgalactosamine $(\alpha-\mathrm{D}$-GalNAc) and $\beta$-D-Nacetylglucosamine ( $\beta$-D-GlcNAc). After the 10th day of gland development, mucous cells changed into serous cells, which initially react weakly positively with PNA, SBA and WGA. The staining with these lectins become more intense starting from 10th day. Therefore, this validated that serous cells contained $\alpha$-D-GalNAc-D-GalNAc in addition to $\beta$-D-Gal, $\alpha$-D-GalNAc and $\beta$-D-GlcNAc. These results have suggested that $\alpha$-D-GalNAc-D-GalNAc is a sugar residue that is specific to mature serous granules, and that the extensive maturation of serous granules occurs after the disappearance of mucous granules. Thus, the mucous cells may play an important role in producing glycoconjugates until the serous cells have appeared and fully matured. Almost similar types of results have been reported by Takada, Aiyama, Ikeda and Okamoto (2001) in early postnatal mouse parotid gland as well.

Positive reaction of acinar cells to SBA indicated that $\mathrm{N}$-acetylgalactosamine could be a terminal sugar residue only in the $\beta$-anomeric form (PEDINI, CECCARELLI and GARGIULO, 1994). In our study, UEA-I stained acinar cells homogeneously unlike the study of Pedini, Ceccarelli and Gargiulo (1994). These differences between morphologically similar acinar cells in the ovine and canine parotid glands may be related to activation and/or deactivation of glycosidases and glycosyltransferase during the anabolic and catabolic phases of secretory glycoconjugate metabolism (ACCILI, MENGHI and MATERAZZI, 1989). Besides, UEA-I can be attributed to the presence of fucose in O-glycosidically linked secretory glycoproteins (SCHULTE and SPICER, 1983). Our staining with Con-A and WGA is in line with the results of Pedini, Ceccarelli and Gargiulo (1994) shown moderate and strong staining pattern with ConA and WGA, indicating that glycoconjugates containing mannose and $\mathrm{N}$-acetylglucosamine were homogeneously presence in acinar cells.

Gargiulo, Pedini and Ceccarelli (1993) have reported that all serous cells in the horse parotid gland were unreactive with the lectins SBA, UEA-I, PNA and WGA employed. This is entirely contrary to our present findings, except for no reaction to PNA in serous epithelial cells. Of two lectins DBA and SBA exhibiting a similar affinity for $\alpha-D-G a l N A c$ in the study of Gargiulo, Pedini and Ceccarelli (1993), the fact that SBA did not react with serous cells in the horse parotid gland but with ones in the ovine parotid gland means that DBA has a higher affinity for $\alpha$-D-GalNAc than SBA in at least horse. However, an extreme discrepancy between these two species may result from several reasons such as the purity of lectins used and their vendor, preparation of lectin solutions in the laboratory and an unknown methodological fault. Because the products of both serous cells and mucous cells may undergo a substantial change during tissue processing due to their contents.

Laden, Schulte and Spicer (1984) have reported that serous cells in human parotid gland stained very weakly with the lectins $\mathrm{BSA}-\mathrm{IB}_{4}$, SBA and UEA-I in an autopsy study. Likewise, McMahon, Benbow, Lofthouse et al. (1989) indicated that serous cells in the human parotid gland reacted with the lectins Con-A, BSA-IB ${ }_{4}$, SBA, UEA-I and WGA from very weakly to moderately. These results are similar to our findings, although relatively little to moderate variations.

Munyala, Liumsiricharoen, Pongket et al. (2009) stated that the lectins Con-A, SBA, UEA-I and WGA staining is positive in the serous cells of Malayan pangolin (Manis javanica), especially with a large amount of mannose. These results show similarity with our findings, besides finding similar results in fallow - deer (PEDINI, CECCARELLI, GARGIULO et al., 1997) and lesser mouse deer (ADNYANE, WRESDIYATI, WIBAWAN et al., 2006).

In a study on human parotid gland mucoepidermoid carcinoma, Sobral, Rego, Cavalacanti et al. (2010) have reported that acinar and luminar cells of the excretory cell in normal parotid gland were recognized by UEA-I but not Con-A with a weak staining pattern. Depending on grades of mucoepidermoid carcinoma, however, tumors exhibited a variable staining pattern with the lectins UEA-I and Con-A, 
besides observing stronger staining with UEA-I than with Con-A.

In conclusion, lectins and their complimentary carbohydrates are located on the surfaces of opposing cells, which can be of the same type or different types. Their interactions are required for cell differentiation, development, and most importantly, pathological states in which harmful cells, e.g. cancer cells, can use carbohydrate moieties to escape recognition by the immune cells as they migrate through the body. Therefore, it is essential that characterization of the glycoconjugate profiles in different species could be understood detailed structure and function of parotid gland in both normal- and abnormal states.

Acknowledgements: We would like to thank Süleyman Demirel University Scientific Research Projects Coordination Unit for financial support (Project No: 2946-YL-11).

\section{References}

ACCILI, D., MENGHI, G. and MATERAZZI, G. Biochemical analysis and lectin histochemistry for detecting complex carbohydrates in the cat parotid gland. Archives of Biology, 1989, vol. 100, p. 337-351.

ACCILI, D., MENGHI, G., BONDI, AM. and SCOCCO, P. Glycoconjugate composition of mammalian parotid glands elucidated in situ by lectins and glycosidases. Acta Histochemica, 1992, vol. 92, n. 2, p. 196-206. http://dx.doi.org/10.1016/S0065-1281(11)800814. PMid:1379407.

ADNYANE, IKM., WRESDIYATI, T., WIBAWAN, IWT., WINARTO, A. and AGUNGPRIYONO, S. The morphological study of salivary gland of the lesser mouse deer (Tragulus javanicus) with special reference to the distribution of glycoconjugates and lysozyme. In Proceedings of AZWMP, 2006. Bangkok: Faculty of Veterinary Science, Chulalongkorn University, 2006. p. 34.

BATH-BALOGH, M. and FEHRENBACH, MJ. Illustrated dental embryology, histology, and anatomy. 3rd ed. Philadelphia: Saunders, 2011. 344 p.

GARGiulo, AM., PEDINI, V. and CECCARELli, P. Lectin histochemistry of glycoconjugates in horse salivary glands. Anatomia, Histologia, Embryologia, 1993, vol. 22, n. 1, p. 83-90. http://dx.doi. org/10.1111/j.1439-0264.1993.tb00344.x. PMid:8489050.

GRÖSCHL, M. The physiological role of hormones in saliva. BioEssays, 2009, vol. 31, n. 8, p. 843-852. http://dx.doi.org/10.1002/ bies.200900013. PMid:19554609.

GUYTON, AC. and HALL, JE. Textbook of medical physiology. 12th ed. Philadelphia: Saunders, 2010. 1120 p.

HAND, AR. and FRANK, ME. Fundamentals of oral histology and physiology. 1st ed. USA: Wiley-Blackwell, 2015. 296 p.

IKEDA, R. and AIYAMA, S. Developmental changes in mucous cells of the early postnatal rat parotid gland: an ultrastructural and histochemical study. Archives of Histology and Cytology, 1997, vol. 60, n. 2, p. 185-193. http://dx.doi.org/10.1679/aohc.60.185. PMid:9232182.

IKEDA, R. and AIYAMA, S. Developmental changes in sugar residues and secretory protein in mucous cell of the early postnatal rat parotid gland. The Anatomical Record, 1999, vol. 255, n. 2, p. 155-161. http:// dx.doi.org/10.1002/(SICI)1097-0185(19990601)255:2<155::AIDAR5>3.0.CO;2-4. PMid:10359516.

IKEDA, R., AIYAMA, S., TSUJIMURA, T. and OKAMOTO, K. Developmental changes in the fine structure and histochemical properties of mucous cells in the parotid gland of the infant Japanese, Macaque. Archives of Histology and Cytology, 2001, vol. 64, n. 5, p. 545-553. http://dx.doi.org/10.1679/aohc.64.545. PMid:11838714.
JEZERNIK, K. and PIPAN, N. Lectin-binding pattern in parotid acinar cells: the fracture-labelling method and post-embedding staining. Histochemistry, 1986, vol. 85, n. 6, p. 515-521. http:// dx.doi.org/10.1007/BF00508434. PMid:2430921.

KARAÇALI, S. Glikobiyoloji güncel moleküler biyoloji. Turkish Journal of Veterinary and Animal Sciences, 2003, vol. 27, p. 489-495.

KIMURA, J., HABATA, I., ENDO, H., RERKAMNUAYCHOKE, W., KUROHMARU, M., YAMADA, J., NISHIDA, T. and TSUKISE, A. Histochemistry of complex carbohydrate in the major salivary glands of hoary bamboo rats (Rhizomys purinosus). Anatomia, Histologia, Embryologia, 1998, vol. 27, n. 3, p. 147-153. http:// dx.doi.org/10.1111/j.1439-0264.1998.tb00172.x. PMid:9652141.

KOEPPEN, MN. and STANTON, BM. Berne \& Levy Physiology. 6th ed. Philadelphia: Mosby, 2008. 844 p.

LADEN, SA., SCHULTE, BA. and SPICER, SS. Histochemical evaluation of secretory glycoproteins in human salivary glands with lectin- horseradish peroxidase conjugates. The Journal of Histochemistry and Cytochemistry, 1984, vol. 32, n. 9, p. 965-972. http://dx.doi. org/10.1177/32.9.6379041. PMid:6379041.

LIENER, IE., SHARON, N. and GOLDSTEIN, IJ. The lectins: properties, functions, and applications in biology and medicine. Orland: Academic Press, 1986. 618 p.

MCMAHON, RFT., BENBOW, EW., LOFTHOUSE, AK. and STODDART, RW. Human salivary gland glycoconjugates: a lectin histochemical study. The Histochemical Journal, 1989, vol. 21, n. 11, p. 663-674. http://dx.doi.org/10.1007/BF01002487. PMid:2584065.

MESCHER, A. Junqueira's basic histology: text and atlas. 13th ed. New York: McGraw-Hill Medical, 2013. 480 p.

MILETICH, I. and TUCKER, AS. Salivary glands: development, adaptations and disease. Basel: Karger, 2010.

MUNYALA, R., LIUMSIRICHAROEN, M., PONGKET, P., PRAPONG, T. and SUPRASERT, A. Glycoconjugates in the secretory epithelium of the mandibular salivary gland of Malayan Pangoin (Manis javanica). Journal of Veterinary Medicine, 2009, vol. 19, n. 2, p. 162-170.

OMELYANENKO, NP., SLUTSKY, LI. and MIRONOV, SP. Connective tissue: histophysiology, biochemistry, molecular biology. 1st ed. Boca Raton: CRC Press, 2013. 638 p.

PEDERSEN, AM., BARDOW, A., JENSEN, SB. and NAUNTOFTE, B. Saliva and gastrointestinal functions of taste, mastication, swallowing and digestion. Oral Diseases, 2002, vol. 8, n. 3, p. 117-129. http:// dx.doi.org/10.1034/j.1601-0825.2002.02851.x. PMid:12108756.

PEDINI, V., CECCARELLI, P., GARGIULO, AM. and DALL'AGLIO, C. Histochemical study of lectin binding in the major salivary glands of adult fallow-deer (Dama dama L.). Acta Histochemica, 1997, vol. 99 , n. 1, p. 81-89. http://dx.doi.org/10.1016/S0065-1281(97)800116. PMid:9150800.

PEDINI, V., CECCARELLI, P. and GARGIULO, AM. Localization of glycoconjugates in dog parotid gland by lectin histochemistry. Veterinary Research Communications, 1994, vol. 18, n. 4, p. 269279. http://dx.doi.org/10.1007/BF01839193. PMid:7831756.

PEDINI, V., CECCARELli, P. and GARGIULO, AM. A lectin histochemical study of the zygomatic salivary gland of adult dogs. Veterinary Research Communications, 1995, vol. 19, n. 5, p. 363373. http://dx.doi.org/10.1007/BF01839318. PMid:8560753.

REECE, WO. Functional anatomy and physiology of domestic animals. Philadelphia: Lippincott Williams \& Wilkins, 2005.

RHODES, JM. and MILTON, JD. Methods in molecular medicine. New Jersey: Humana Press, 1998. Lectin methods and protocols, vol. 9. 
ROTH, J. Lectins for histochemical demonstration of glycans. Histochemistry and Cell Biology, 2011, vol. 136, n. 2, p. 117-130. http://dx.doi.org/10.1007/s00418-011-0848-5. PMid:21805335.

SCANLON, VC. and SANDERS, T. Essentials of anatomy and physiology. Philadelphia: F.A. Davis Company, 2007.

SCHULTE, BA. and SPICER, SS. Light microscopic detection of sugar residues in glycoconjugates of salivary glands and the pancreas with lectin-horseradish peroxidase conjugates. I. Mouse. The Histochemical Journal, 1983, vol. 15, n. 12, p. 1217-1238. http:// dx.doi.org/10.1007/BF01002741. PMid:6643118.

SCHULTE, BA. and SPICER, SS. Light microscopic detection of sugar residues in glycoconjugates of salivary glands and the pancreas with lectin-horseradish peroxidase conjugates. II. Rat. The Histochemical Journal, 1984, vol. 16, n. 1, p. 3-20. http://dx.doi.org/10.1007/ BF01003432. PMid:6200459.

SOBRAL, APV., REGO, MJBM., CAVALACANTI, CLB., CARVALHO JUNIOR, LB. and BELTRÃO, EI. ConA and UEA-I lectin histochemistry of parotid gland mucoepidermoid carcinoma. Journal of Oral Science, 2010, vol. 52, n. 1, p. 49-54. http://dx.doi. org/10.2334/josnusd.52.49. PMid:20339232.

SÖZMEN, M., BROWN, P. and EVESON, J. Lectin histochemistry of dog major and minor salivary glands. Veterinary Research, 1999, vol. 30, n. 6, p. 583-593. PMid:10596406.

TAKADA, K., AIYAMA, S. and IKEDA, R. Morphological and histochemical changes in the secretory granules of mucous cells in the early postnatal mouse parotid gland. Archives of Histology and
Cytology, 2001, vol. 64, n. 3, p. 259-266. http://dx.doi.org/10.1679/ aohc.64.259. PMid:11575422.

TOLSON, ND., DALEY, TD. and WYSOCKI, GP. Lectin probes of glycoconjugates human salivary glands: 1. Journal of Oral Pathology, 1985, vol. 14, n. 7, p. 523-530. http://dx.doi.org/10.1111/j.1600-0714.1985. tb00525.x. PMid:3928847.

TORTORA, GJ. and DERRICKSON, B. Principles of anatomy and physiology. New York: John Wiley \& Sons, 2012.

ÜNÜBOL, AS. and UYSAL, H. Glikoproteinlerin yapisi ve fonksiyonlari. Frrat Üniversitesi Sağlık Bilimleri Veteriner Dergisi, 2010, vol. 24, n. 2 , p. 107-114.

VIGNESWARAN, N., HANEKE, E. and HORNSTEIN, OP. A comparative lectin histochemical study of major and minor salivary glands with special reference to the labial glands. Archives of Oral Biology, 1989, vol. 34, n. 9, p. 739-748. http://dx.doi.org/10.1016/00039969(89)90081-2. PMid:2624565.

ZELLES, T., PURUSHOTHAM, KR., MACAULEY, SP., OXFORD, GE. and HUMPHREYS-BEHER, MG. Saliva and growth factors: the fountain of youth resides in us all. Journal of Dental Research, 1995 , vol. 74 , n. 12, p. 1826-1832. http://dx.doi.org/10.1177/0 0220345950740120301. PMid:8600176.

Received March 15, 2015 Accepted April 10, 2016 